\title{
Breast reconstruction with permanent expander: a different approach
}

\author{
Reconstrução mamária com expansor definitivo: enfoque diferenciado
}

RiNEDE LUIS MANFREDINI ${ }^{1}$

Study conducted at Hospital de Caridade de Erechim and Uniclínica/UNIMED Erechim, Erechim, RS, Brazil.

Paper submitted to obtain the status of Full Member of the SBCP.

Submitted to SGP (Sistema de Gestão de Publicações/Manager Publications System) of RBCP (Revista Brasileira de Cirurgia

Plástica/Brazilian Journal of Plastic Surgery).

Received: March 11, 2011 Accepted: August 13, 2011

\begin{abstract}
Background: Immediate or delayed breast reconstruction with tissue expanders can be performed in one or several surgical sessions. We opted to perform breast reconstruction over several sessions. The aim of this study was to report our experiences with the breast reconstruction technique involving Becker permanent tissue expanders and complete expander coverage with a flap comprising the pectoralis major, pectoralis minor, serratus anterior, and rectus abdominis aponeurosis. Methods: The medical records of 21 patients who underwent postmastectomy breast reconstruction with Becker permanent tissue expanders were retrospectively analyzed. Results: During muscle flap preparation, the aponeurotic dissection was performed 6-8 cm below the inframammary crease, aiming at full expander coverage without tension, enabling lower suturing in the inframammary crease, and avoiding disruption of the pectoralis major attachments. Only two patients developed infection, one in the first postoperative week and the other in the third postoperative month. Conclusions: The flap comprising the pectoralis major, pectoralis minor, serratus anterior, and rectus abdominis aponeurosis is a good choice for breast reconstruction with permanent tissue expanders because it ensures adequate expander and skin-flap protection. Moreover, the technique enables tissue expansion without confining the expanders in the submuscular cavity.
\end{abstract}

Keywords: Breast neoplasms, Mastectomy, Mammaplasty, Tissue-expansion devices

\section{RESUMO}

Introdução: As reconstruções de mama imediatas ou tardias com uso de expansores podem ocorrer em um ou mais de um tempo cirúrgico. Optou-se por reconstruções em mais de um tempo cirúrgico, com expansores definitivos tipo Becker. Este estudo teve como objetivo demonstrar a utilização da técnica de reconstrução mamária com expansor definitivo tipo Becker, com retalho dos músculos peitoral maior e menor, serrátil anterior e aponeurose do músculo reto abdominal para cobertura completa do expansor. Métodos: Estudo retrospectivo, por meio de análise de prontuário, incluindo 21 pacientes submetidas a reconstrução mamária com expansor permanente. Resultados: Na confecção do retalho muscular, é necessária a realização de dissecção abaixo do sulco submamário definido no pré-operatório, com o propósito de cobertura total do material aloplástico usado na reconstrução, englobando a aponeurose do músculo reto abdominal, $6 \mathrm{~cm}$ a $8 \mathrm{~cm}$ abaixo do sulco submamário, evitando-se lesão de sua continuidade com o músculo peitoral maior. Neste estudo, duas pacientes apresentaram infecção, uma delas na primeira semana de pós-operatório e a outra, no terceiro mês. Conclusões: A utilização do retalho dos músculos peitoral maior e menor, serrátil anterior e bainha do músculo reto abdominal é uma boa opção nas reconstruções mamárias com utilização de expansor definitivo de tecidos, visto que promove proteção adequada ao expansor e aos retalhos cutâneos que se posicionam sobre ele. Além disso, a técnica permite expansão tecidual, sem que os expansores fiquem encarcerados ou presos à loja muscular.

Descritores: Neoplasias da mama. Mastectomia. Mamoplastia. Dispositivos para expansão

1. Plastic surgeon, Full Member of the Brazilian Society of Plastic Surgery, Erechim, RS, Brazil. 


\section{INTRODUCTION}

According to the National Institute of Cancer ${ }^{1}$, the word "cancer" indicates diseases with disordered cell growth, which invade tissues and/or organs and are classified as malignant or benign depending on the degree of invasiveness. Consequently, people fear the word, which has long been synonymous with pain, suffering, shame, and death. According to Sant'Anna ${ }^{2}$, in the case of invasive breast diseases, these feelings intensify, because the breasts are considered a symbol of femininity.

Breast cancer, according to Menke et al. ${ }^{3}$, is a malignant neoplasm with the highest incidence among women, representing $20 \%$ of all tumors and accounting for $15 \%$ of the tumor-related deaths in women. Worldwide, it is considered a public health problem, with 5 million new cases estimated within 5 years. According to the National Cancer Institute ${ }^{4}$, the associated mortality in Brazil is high because of late diagnosis. It is the most common cancer in women, representing $22 \%$ of the new cases annually, with an average 5-year survival rate of $61 \%$. The World Health Organization (WHO) estimated 49,240 new cases for 2010 globally. In 2008, 11,860 deaths were attributed to this type of cancer, almost all (11,735 cases) in women.

In Brazil, 9,240 new cases of breast cancer in women were expected for 2010, with an estimated risk of 49 cases per 100,000 women. In southern Brazil, the estimated risk was 64 new cases per 100,000 women, one of the highest rates in the country. In Rio Grande do Sul, 4,750 new cases were estimated for 2010, and in Porto Alegre, the state capital, the estimated incidence was 1,040 new cases.

Breast cancer is the second leading cause of death among women in Brazil because of late diagnosis, which is common in developing and underdeveloped countries. In developed countries, despite the increased incidence of breast cancer, the mortality has reduced because of early detection ${ }^{1}$.

Breast cancer is considered a multifactorial disease, involving both genetic and environmental factors. Mammary carcinogenesis is a complex process, and is divided into initiation, promotion, and progression. In initiation, carcinogens trigger genetic events and activated oncogenes promote abnormal cell proliferation. Tumorsuppressor genes inhibit cell division, repairing deoxyribonucleic acid (DNA) defects. BRCA1 and BRCA2 genes produce proteins required for defective DNA repair. Changes in these genes result in chromosomal instability and inability to repair cell errors in breast tissue. Promotion is a genetic initiating event stimulated by steroid hormones, inflammatory reactions, and growth factors. In progression, the tumor is already established and is capable of tissue invasion and metastasis ${ }^{3}$.
Patients with early stage breast cancer can opt for quadrantectomy or modified radical mastectomy, which may be accompanied by sentinel lymph node removal if the tumor diameter is $\leq 3 \mathrm{~cm}$. Clinical nodular impairment should not be present during sentinel lymph node removal. Intraoperatively, upon identifying and removing the sentinel lymph node, the need for withdrawal of all chains of axillary lymph nodes can be determined, a procedure called axillary dissection ${ }^{1}$.

Surgery is the treatment of choice for breast cancer. The classical radical mastectomy was introduced by William Halsted in 1894, becoming a landmark in breast cancer treatment ${ }^{3}$. Today, for early stage breast cancer, conservative surgical procedures such as quadrantectomy with sentinel lymph node are electively performed; in more advanced cases, modified radical mastectomy with preservation of the pectoral muscles and sentinel lymph node analysis, with or without axillary dissection, is the most suitable treatment.

After quadrantectomy and mastectomy, women can opt for reconstructive surgery with the insertion of silicone implants or saline, or temporary or permanent tissue expanders, through the rectus abdominis, latissimus dorsi, or microsurgical muscle flaps ${ }^{5}$.

With the increasing incidence of breast cancer, more cases of mastectomy will be performed and more patients will seek breast reconstruction by a specialist. The plastic surgeon should be prepared to face this disease and, with knowledge and technical skills, greatly contribute to its treatment. Importantly, patients who undergo breast reconstruction have better recovery from the oncological viewpoint, regaining their self-esteem and facing adjuvant treatments such as chemotherapy and radiotherapy with greater encouragement and confidence.

Breast reconstruction can be performed immediately or at a later stage (delayed), according to the preference of the professional or service in charge of the procedure as well as by the patient's choice. Primary or immediate reconstruction is justified by the breast cancer specialist during mastectomy, ensuring better planning of tissue availability for reconstruction, maintenance of tissue vitality, and preservation of larger amounts of skin and muscles. Moreover, the reconstruction is faster because tissues are already available during the surgery, without the need of waiting for 6-12 months to correct the breast deformity ${ }^{6}$.

Proponents of delayed breast reconstruction justify their position on the basis of the ability to avoid bruising, infection, bleeding, and loss of muscle flap during mastectomy. They also argue that postoperative radiotherapy can be performed even if not indicated initially by the breast cancer specialist; the need of postoperative radiotherapy may be reconsidered according to the histopathological result, and the treatment increases the risk of complications in the flaps used for breast reconstruction. The delayed surgery is technically 
easier, with less tissue dissection, more reliable skin flaps, and smaller area of "dead" space. In delayed breast reconstruction, mastectomy and vitality of the local skin flaps are already determined and, in cases of radiotherapy, tissues altered by this procedure are removed and replaced with autologous tissues instead of immediate prosthetic repair 6 .

Immediate or delayed breast reconstruction with tissue expanders can be performed in one or several surgical sessions. At our Service, reconstruction is performed over several sessions to enable better adaptation between the reconstructed breast and the contralateral breast. In nippleareolar complex reconstruction, breast volume, size, and shape can be adjusted with or without expansion and repositioning the inframammary crease, which also allows the contralateral breast to be improved.

In our practice, we use adjustable permanent tissue expanders for breast reconstruction, because the procedure can be performed with the breast cancer specialist's participation, enabling suitable preoperative assessment and discussion with the patient regarding the suitable reconstruction technique and the need of postoperative radiotherapy. Such expanders allow dynamic execution of the technique without the use of tissues from other regions, such as latissimus dorsi and rectus abdominis flaps.

Thromboembolic phenomena greatly increase in long anesthetic and surgical procedures; moreover, the risk of infection increases after 4 hours of surgery, putting the implants used for breast reconstruction at risk $^{6}$. Medical staff integration, adequate preoperative planning, and surgical sequencing in compliance with the schedule ensure quick mastectomy and immediate breast reconstruction without intraoperative surprises, which could prolong the surgery and thus increase its inherent risks.

The benefits of immediate breast reconstruction are that patients do not feel mutilated, have their mammary gland unit rebuilt, rapidly return to social life, and regain their previous physical identity.

Breast implants, which emerged in the 1960s, feature different sizes and shapes: round, anatomical, of inferior pole and high, low, medium, or super-high profiles. In Brazil, the implants available for breast reconstruction are as follows: silicone implants, which have a smooth, textured, or polyurethane foam outer surface and an internal padding with silicone gel; tissue expanders, which have a smooth or textured outer surface and an empty interior that can be filled with saline solution through a remote or external valve; and Becker permanent tissue expanders, which are double-lumen devices with a textured outer surface, silicone gel (35-50\% of the total expander volume) in the anterior layer, and an empty posterior cavity that can be filled with saline solution (50-65\% of the total expander volume) through an external valve $^{7}$.
The alloplastic materials for breast reconstruction, such as tissue expanders and silicone implants, have complications related to their use, including infection (1-10\% incidence) and Baker grade 3 or 4 capsular contracture $(2-5 \%$ incidence), which is the most common complication associated with breast implants in the long term ${ }^{6}$. Capsular contracture is classified, according to the Baker grading system, as follows: Baker grade 1, the breast has a soft consistency and the implant is not palpable; Baker grade 2, slightly palpable capsule; Baker grade 3, the implant is not visible and has palpable hardening; and Baker grade 4, the same characteristics of Baker grade 3 associated with pain. Another possible complication is emptying of the permanent tissue expander, because of problems related to the retention valves in the device, leading to decreased projection of the reconstructed breast tissue.

Implant-related breast hardening occurs in $30-35 \%$ of the patients within 2 years postoperatively. Factors that may contribute to the onset of capsular contracture are subclinical infection, undrained hematoma, seroma, and contamination of the operated area ${ }^{6}$.

The technique of breast reconstruction with tissue expanders was introduced in 1980 by Radovan, and was refined by Argenta. In this technique, expander coverage depends on muscle or myocutaneous flaps because the surgery is aggressive, with extensive skin resection, resulting in the lack of skin for tissue closure. The expanders used have a smooth surface, and are indicated for all patients with good skin extension and soft tissue. The location of choice for expander placement is the submuscular cavity, with dissection and division of the pectoralis major parallel to the orientation of its muscle fibers and close to the fourth or fifth ribs. The upper dissection is facilitated whereas the lower and lateral dissections are difficult, because the anatomical bases are unclear. The lower dissection is performed less than $2 \mathrm{~cm}$ below the original inframammary crease, considering that the expander tends to rise during the expansion. Muscle fibers near the sternum are preserved, avoiding expander migration toward the medial portion. After the submuscular cavity is prepared, the expander is placed and is wholly or partly covered. Expanders with a textured surface enable better adherence to the surrounding tissues, preventing their migration or rotation. The expander volume is determined on the basis of the contralateral breast. The empty expander is placed in the submuscular cavity, and after muscle closure, it is inflated with 100-200 ml of saline solution, respecting the tissue expandability ${ }^{8}$. This technique has been defended by Guimarães et al. ${ }^{9}$, and has satisfactory results and complications comparable to those reported in the world literature.

The options for expander placement include positioning just below the pectoralis major, pectoralis minor, and 
serratus anterior with total muscle coverage, including these muscles and the rectus abdominis muscle sheath. This technique causes, as an undesirable effect, flattening of the inferior pole of the reconstructed breast ${ }^{8}$. When muscle flaps are unavailable, the lower portion of the expander can be covered with subcutaneously placed bioprosthetic materials such as AlloDerm ${ }^{10}$. AlloDerm is an acellular dermal matrix of sterilized cadaver skin without antigenic components, maintaining collagen, elastin, hyaluronic acid, fibronectin, proteoglycans, and vascular channels. This array is part of the receptor tissue, protecting the bottom of the expander ${ }^{11}$.

In Brazil, the National Health Surveillance Agency (Anvisa) does not allow the marketing of AlloDerm, making its use unfeasible. Therefore, breast reconstruction is performed with Becker permanent tissue expanders and complete expander coverage by using a flap comprising the pectoralis major, pectoralis minor, serratus anterior, and anterior aponeurosis of the rectus abdominis.

The aim of this study was to report our experiences with the breast reconstruction technique involving Becker permanent tissue expanders and complete expander coverage with the muscle flap; here, we discuss the technical details and potential complications of the procedure.

\section{METHODS}

In this study, the medical records of 21 patients who underwent postmastectomy breast reconstruction with Becker permanent tissue expanders at our Service between January 2008 and June 2010 were retrospectively analyzed. The candidates for breast reconstruction were determined by the Mastology Service of the hospital, after considering the histopathological diagnosis and treatment plan or for avoiding multiple surgeries in at-risk patients (BRCA1 or BRCA2 positive).

During the preoperative visit, the patients were informed regarding the reconstructive procedure, reconstructive material, importance of the surgical procedures, occurrence of pain and other possible complications, and surgical limitations, and their signed consent was obtained. Preoperative examinations were performed according to age, the presence of comorbidities, the indicated expander volumes, and the need of symmetrization of the contralateral breast.

At our Service, Siltex Round Becker 50 expanders (Mentor Corporation) were used for breast reconstruction. These expanders have silicone gel in the anterior portion (50\% of the device) and the posterior chamber $(50 \%$ of the device) can be filled with saline solution through a remote valve. The total volume of infused saline solution was determined on the basis of the total volume of the expander, the size proposed to be achieved, and the volume of the contralateral breast, with $20 \%$ more expansion possible than the volume predetermined by the factory. In the contralateral breasts, breast implants were used and breast reduction with breast implants or mastopexy was performed, as needed.

The inclusion criteria for breast reconstruction with permanent tissue expanders were as follows: patients who underwent or were indicated for modified radical mastectomy due to breast carcinoma, and patients with high risk of developing breast cancer, with an indication of prophylactic adenomastectomy.

The exclusion criteria were patient's disagreement with undergoing breast reconstruction, presence of comorbidities with clinical or cardiological contraindications to the procedure, and patient's expectation of an unattainable result with the procedure during the preoperative assessment.

\section{Surgical Technique}

Modified radical mastectomy or prophylactic adenomastectomy was performed in one surgical session via an inverted$\mathrm{T}$ or vertical incision according to the scar that would be used for contralateral breast symmetrization.

General anesthesia was used in all cases. The breast cancer specialist, along with the plastic surgeon, protected the flaps resulting from the mastectomy, avoiding possible skin damage. Breast retractors were not used, and skin flap thickness of 0.5-1 cm was maintained, preserving skin vascularity. The pectoralis major, pectoralis minor, serratus anterior, and anterior aponeurosis of the rectus abdominis were used for the muscle flap. The aponeurosis was dissected approximately $6-8 \mathrm{~cm}$ below the inframammary crease, making the flap longer and enabling lower suturing without tension in the inframammary crease. This maneuver also prevents disruption of the pectoralis major attachments, ensuring the availability of adequate lower tissue to cover the alloplastic material (Figure 1).

The expander was entirely placed in the submuscular plane, followed by suturing from the anterior aponeurosis of the rectus abdominis to the location of the predetermined inframammary crease, achieving proper contour of the inferior pole of the reconstructed breast and breast expander protection. Then, the remote valve was connected to the expander hose, with the valve located laterally and inferiorly to the expander to avoid device puncture (Figure 2).

The expander was initially not expanded to avoid tissue tension. The valve-expander assembly was tested to assess whether the system was operating properly, and then, saline solution with methylene blue was injected. This strategy helped to identify valve puncture during expansion, because a reflux of saline solution with methylene blue occurred during puncture, confirming the correct location for infusion. The muscle flap was sutured laterally by joining the pectoralis major to the pectoralis minor with 2-0 Monocryl 
thread. The lower portion of the flap, corresponding to the serratus anterior and anterior aponeurosis of the rectus abdominis, was sutured to the periosteum of the costal arch, to define the inframammary crease, with 2-0 Monocryl thread. The skin flap was closed in two planes with 2-0 and 3-0 Monocryl thread.

The expander cavity was emptied with a suction drain in a Porta-Vac-type closed system. The drain was maintained until the liquid output was less than $15 \mathrm{ml}$. Micropore dressings were placed on the incisions and in the chest tube, followed by coverage with gauze and a surgical bra (Figure 3).

Prophylaxis against pulmonary thromboembolism was achieved with Kendall Ted compression stockings, intermittent pneumatic compression on the lower limbs, early strolling on the surgical day, and administration of low-molecularweight heparin 6 hours after the procedure.

The expansion sessions were started in the second postoperative week and were maintained until the total planned volume was achieved, according to the contralateral breast and patient's desires.

\section{Selected Cases}

A few representative cases are described in the following.

Patient 3: A 35-year-old woman with cancer in the right breast who had undergone modified radical mastectomy with breast reconstruction and immediate contralateral breast symmetrization at another Service. She experienced expander loss in the right breast and ptosis of the contralateral breast. One year after the primary surgery, she sought repair at our Service. First, her right breast was reconstructed with a Becker permanent tissue expander and, in the second procedure, left adenomastectomy and breast reconstruction with a Becker permanent tissue expander were performed. Adenomastectomy was indicated by the oncologist because the patient had prognostic factors for triple-negative breast cancer. In the third procedure, the expander valves were removed and the right nipple-areolar complex was reconstructed (Figures 4 to 6 ).

Patient 9: A 38-year-old woman with bilateral breast cancer who underwent bilateral modified radical mastectomy and immediate reconstruction with Becker permanent tissue expanders (Figures 7 and 8).
Patient 12: A 29-year-old woman with lobular carcinoma in the right breast who underwent delayed breast reconstruction and left breast symmetrization (Figures 9 to 12).

Patient 19: A 42-year-old woman without breast cancer diagnosis but with biopsy showing atypical cells and a family history (her mother) of metastatic breast cancer. Bilateral prophylactic adenomastectomy was performed followed by immediate breast reconstruction with Becker permanent tissue expanders (Figures 13 to 16).

\section{RESULTS}

Table 1 summarizes the demographic data, types of cancer, and breast reconstruction devices employed in the study.

The 21 patients were aged between 25 and 76 years: seven patients were aged 50-59 years, seven were aged 40-49 years, five were under 40 years, and two were over 60 years.

Regarding the types of cancer, seven patients had invasive ductal carcinoma, five had lobular carcinoma, five had invasive carcinoma, two had intraductal carcinoma, and two were not diagnosed with cancer but underwent prophylactic adenomastectomy because of their high risk of breast cancer, based on family history and genetic research.

Breast reconstruction with Becker permanent tissue expanders was immediately performed after mastectomy in 19 patients, and was delayed in only two. Symmetrization of the contralateral breast was not performed in three patients, as per their choice (three patients who underwent bilateral mastectomy and two patients who underwent prophylactic adenomastectomy).

The expanders were used for breast reconstruction and contralateral breast symmetrization as directed by the surgeon. Their volumes ranged from $300 \mathrm{ml}$ to $400 \mathrm{ml}$; the volumes of the prostheses used for symmetrization ranged from $150 \mathrm{ml}$ to $225 \mathrm{ml}$.

Two patients developed infection, one in the first postoperative week and the other in the third postoperative month, coinciding with the second session of chemotherapy. The patient with late local infection was asymptomatic, and the infection was attributed to decline in humoral immunity secondary to chemotherapy. In both cases, the expanders
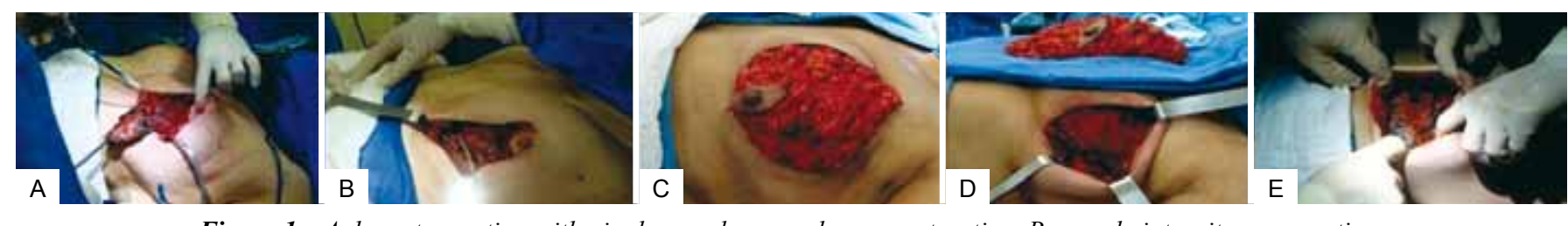

Figure 1 -A, breast resection with nipple-areolar complex reconstruction. B, muscle integrity preservation.

$C$, demarcation of the pectoralis major, pectoralis minor, serratus anterior, and rectus abdominis aponeurosis.

$D$, muscle flap dissected and extensively folded. E, expander completely covered and expander hose output. 

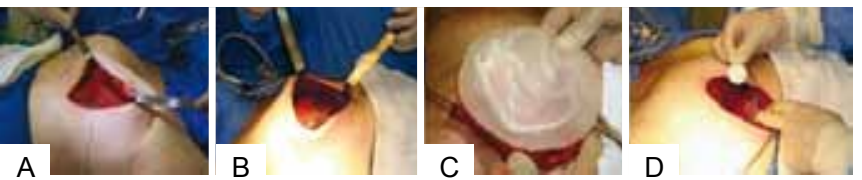

Figure 2-A, placement of an empty expander in the submuscular cavity. $B$, expander covered with intact muscle flap. $C$, expander covered with the muscle flap and chest tube drainage. D, lateral and low remote valve connection in relation to the inframammary crease.
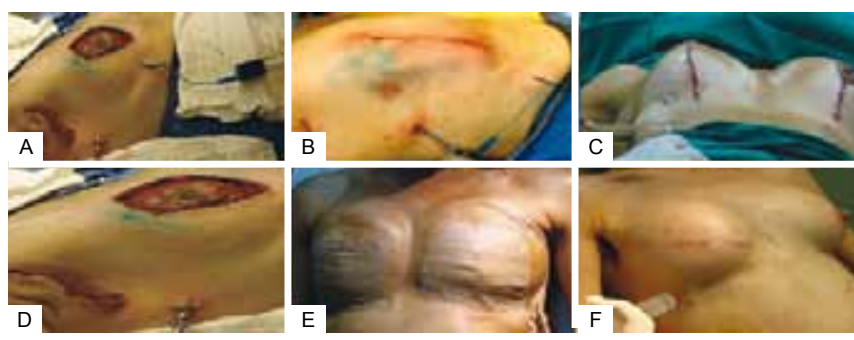

Figure 3-A, valve puncture and leakage of saline solution with methylene blue. $B$, aspect of the sutured skin incision, sentinel lymph node, and drainage tube. $C$, final aspect of the skin incision and inframammary crease with chest tube. $D$, placement of a chest tube at the anterior axillary line in the lateral position. E, Micropore application on the breasts and chest tube. F, tissue expansion.
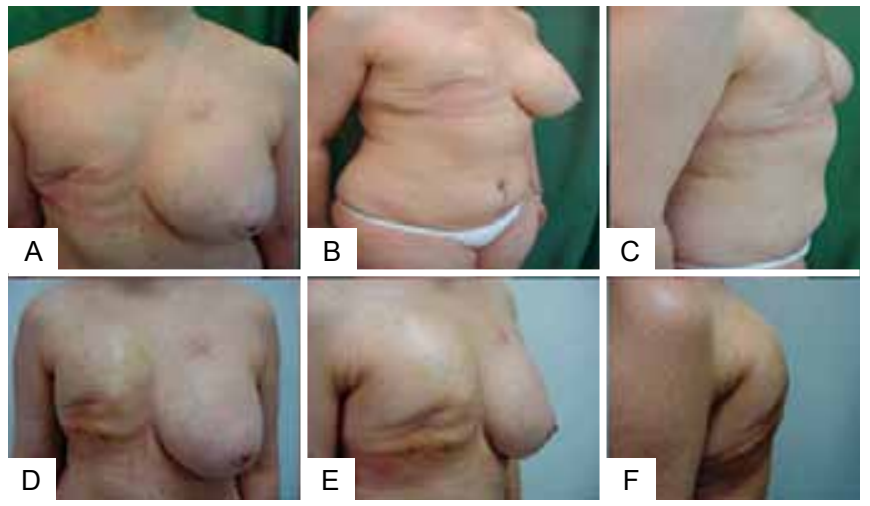

Figure 4-Patient 3. First visit at the Service and first procedure of breast reconstruction with a partially expanded permanent expander in the right breast.

were removed and the patients were successfully treated with intravenous antibiotics. A 59-year-old patient with bilateral breast cancer showed dehiscence of the vertical scar along with expander exposure; the lesion was treated with a thoracic rotation flap, enabling coverage of the exposed area and a good outcome without signs of infection and harm to the reconstruction (Figures 17 to 19). Two patients had seroma with negative cultures and were treated with local aspiration and corticosteroid infiltration after draining the lesion.
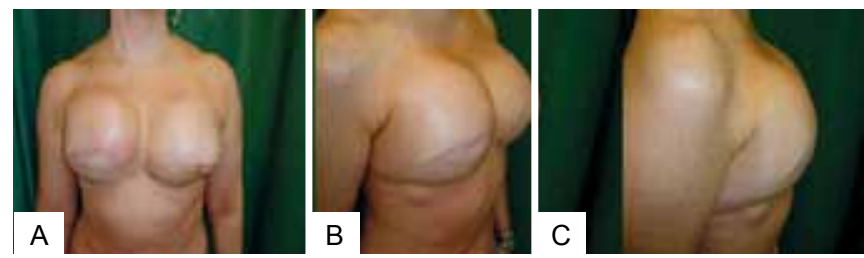

Figure 5 - Patient 3. Second procedure of breast reconstruction with a fully expanded permanent expander in the right breast and a fully expanded permanent expander in the left breast after prophylactic adenomastectomy.
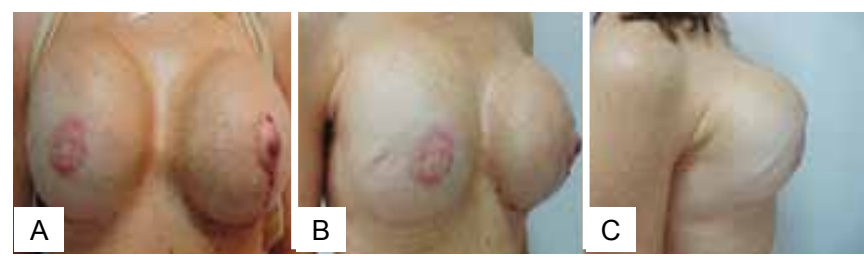

Figure 6-Patient 3. Third surgical procedure involving removal of the expansion valves and reconstruction of the bilateral nipple-areolar complexes.
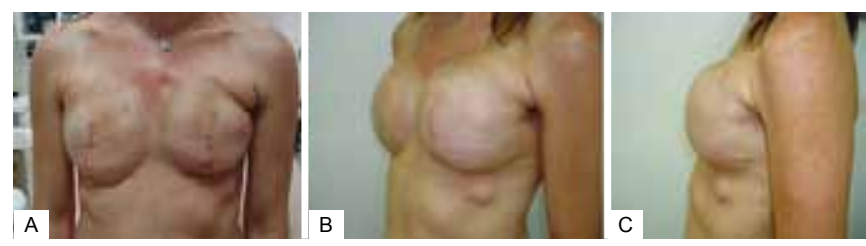

Figure 7 - Patient 9. Bilateral expanders in the expansion phase.
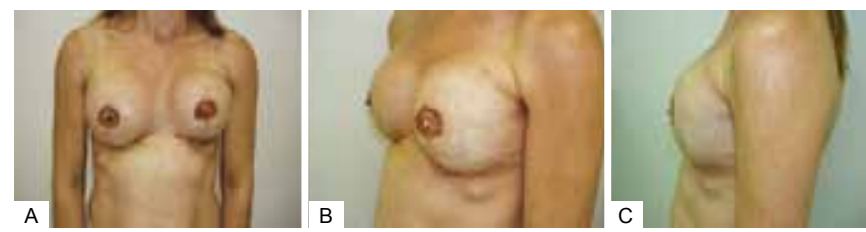

Figure 8-Patient 9. Bilateral nipple-areolar complex reconstruction.

\section{DISCUSSION}

During muscle flap preparation, the dissection should be performed below the inframammary crease as preoperatively defined, aiming at full coverage of the alloplastic material used in reconstruction, encompassing the rectus abdominis aponeurosis from 6 to $8 \mathrm{~cm}$ below the inframammary crease and avoiding disruption of the pectoralis major muscle.

Bioprosthetic materials such as AlloDerm are not available in Brazil for expander coverage in its lower portion ${ }^{8,12,13}$. In addition to being a product without authorization from 

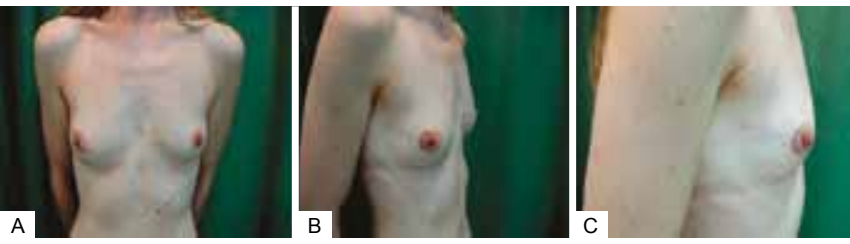

Figure 9 - Patient 12. View of the breast preoperatively.
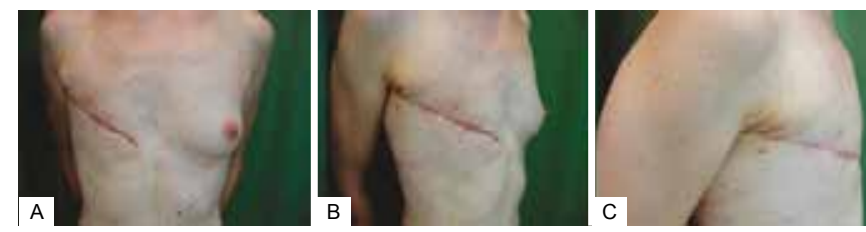

Figure 10-Patient 12. Appearance of the mastectomy performed at another Service.
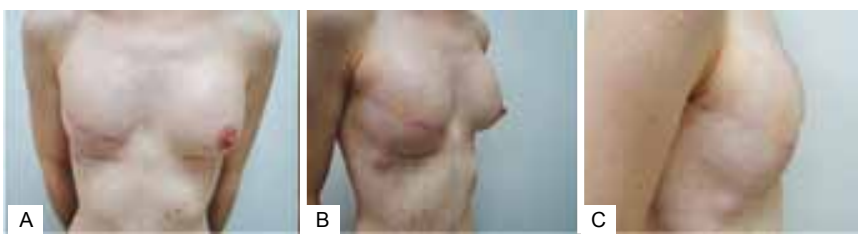

Figure 11 - Patient 12. First procedure of breast reconstruction with a permanent expander in the right breast and contralateral breast symmetrization with a silicone implant.
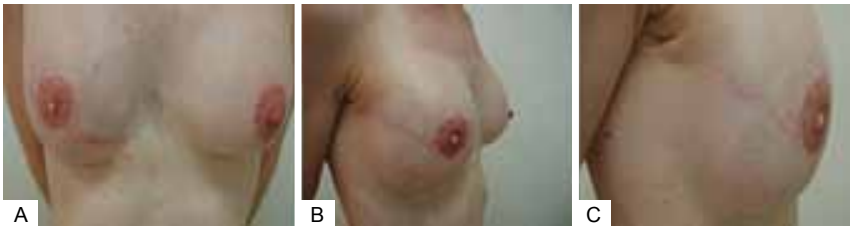

Figure 12 - Patient 12. Second procedure of breast reconstruction involving reconstruction of the nipple-areolar complex, removal of the expander valve, and repositioning of the left nipple-areolar complex.

Anvisa for marketing and use in the country, it is expensive and not composed of autologous tissue, such as the rectus abdominis aponeurotic sheath, which has a lower complication rate and reduced operating costs.

Total expander coverage provides greater protection to the device in cases such as flap dehiscence or skin necrosis, maintaining the expander in the submuscular cavity and preventing infection, contamination, and loss.

The smaller superior detachment of the pectoralis major is justified by the large amount of lower tissue, which properly and completely covers the expander. Therefore, during expansion, lateral, medial, or upper migration of the expander does not occur and dressings with bandages in the

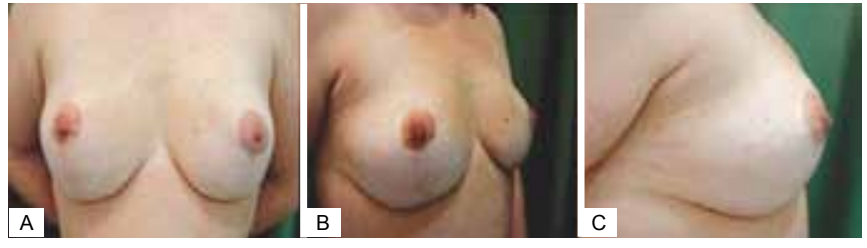

Figure 13 - Patient 13. Preoperative aspect of prophylactic adenomastectomy.
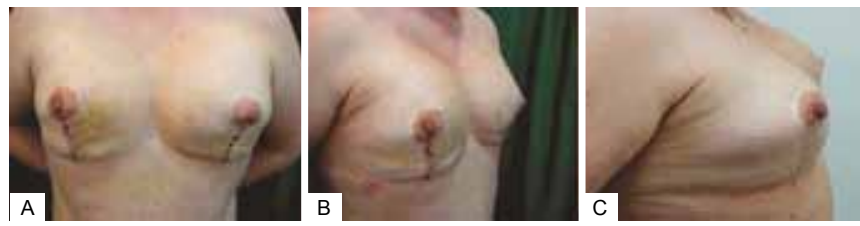

Figure 14 - Patient 13. First procedure of bilateral adenomastectomy involving immediate breast reconstruction with bilateral, partially expanded permanent expanders.
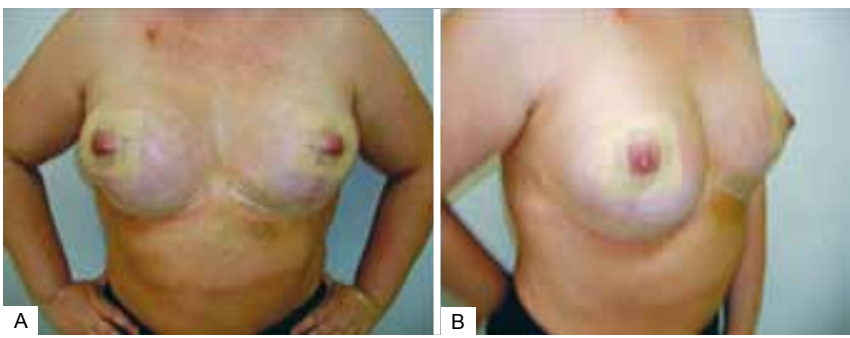

Figure 15 - Patient 13. Second procedure of breast reconstruction with full expansion and removal of the expander valves. Postoperative period of one month.

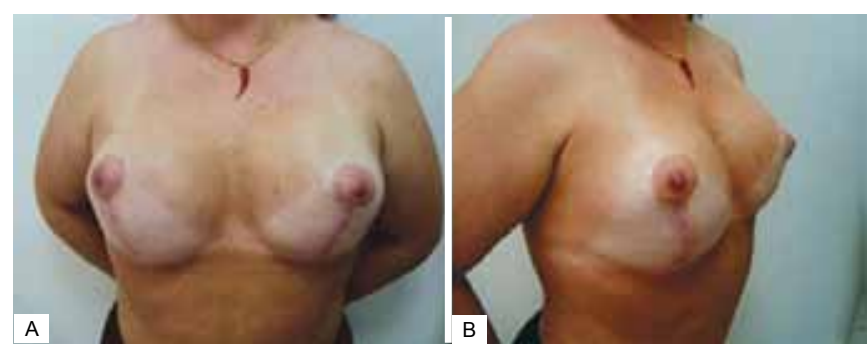

Figure 16-Patient 13. Postoperative period of six months.

upper thoracic region are not required to force the expander to remain in the lower chest region.

During dissection along the pectoralis major, the muscle fibers are weakened and not vascularized, increasing the possibility of wound dehiscence. With the transmuscular approach, detachment of the lower portion of the chest and repositioning of the inframammary crease are difficult, unlike when flap dissection is performed in the inframammary 
Table 1 - Demographic data, types of cancer, and breast reconstruction devices.

\begin{tabular}{|c|c|c|c|c|c|}
\hline Patient no. & $\begin{array}{c}\text { Age } \\
\text { (years) }\end{array}$ & Type of cancer & $\begin{array}{l}\text { Timing of } \\
\text { reconstruction }\end{array}$ & Right breast & Left breast \\
\hline 1 & 76 & Intraductal carcinoma & Immediate & Prosthesis $125 \mathrm{ml}$ & Expander $300 \mathrm{ml}$ \\
\hline 2 & 25 & Lobular carcinoma & Immediate & Expander $400 \mathrm{ml}$ & Prosthesis $125 \mathrm{ml}$ \\
\hline 3 & 35 & Invasive ductal carcinoma & Delayed & Expander $500 \mathrm{ml}$ & Expander $500 \mathrm{ml}$ \\
\hline 4 & 45 & Grade II infiltrating lobular carcinoma & Immediate & Expander $325 \mathrm{ml}$ & Prosthesis $150 \mathrm{ml}$ \\
\hline 5 & 49 & Invasive carcinoma & Immediate & Expander $300 \mathrm{ml}$ & Expander $300 \mathrm{ml}$ \\
\hline 6 & 52 & Ductal carcinoma & Immediate & Expander $400 \mathrm{ml}$ & Without procedure \\
\hline 7 & 57 & Invasive carcinoma & Immediate & Expander $400 \mathrm{ml}$ & Without procedure \\
\hline 8 & 63 & Grade II invasive ductal carcinoma & Immediate & Expander $300 \mathrm{ml}$ & Without procedure \\
\hline 9 & 38 & Bilateral lobular carcinoma & Immediate & Expander $400 \mathrm{ml}$ & Expander $400 \mathrm{ml}$ \\
\hline 10 & 59 & Grade I infiltrating ductal carcinoma & Immediate & Expander $325 \mathrm{ml}$ & Prosthesis $150 \mathrm{ml}$ \\
\hline 11 & 54 & Bilateral ductal carcinoma & Immediate & Expander $300 \mathrm{ml}$ & Expander $300 \mathrm{ml}$ \\
\hline 12 & 29 & Lobular carcinoma & Delayed & Expander $300 \mathrm{ml}$ & Prosthesis $175 \mathrm{ml}$ \\
\hline 13 & 51 & Invasive carcinoma & Immediate & Expander $325 \mathrm{ml}$ & Expander $325 \mathrm{ml}$ \\
\hline 14 & 59 & Bilateral lobular carcinoma & Immediate & Expander $400 \mathrm{ml}$ & Expander $400 \mathrm{ml}$ \\
\hline 15 & 45 & Grade III invasive ductal carcinoma & Immediate & Prosthesis $150 \mathrm{ml}$ & Expander $400 \mathrm{ml}$ \\
\hline 16 & 52 & Invasive carcinoma & Immediate & Expander $400 \mathrm{ml}$ & Prosthesis $150 \mathrm{ml}$ \\
\hline 17 & 29 & High-grade intraductal carcinoma & Immediate & Expander $350 \mathrm{ml}$ & Prosthesis $175 \mathrm{ml}$ \\
\hline 18 & 43 & Grade II invasive ductal carcinoma & Immediate & Expander $400 \mathrm{ml}$ & Prosthesis $225 \mathrm{ml}$ \\
\hline 19 & 46 & Invasive carcinoma & Immediate & Expander $400 \mathrm{ml}$ & Expander $400 \mathrm{ml}$ \\
\hline 20 & 42 & Bilateral prophylactic adenomastectomy & Immediate & Expander $400 \mathrm{ml}$ & Expander $400 \mathrm{ml}$ \\
\hline 21 & 40 & Bilateral prophylactic adenomastectomy & Immediate & Expander $400 \mathrm{ml}$ & Expander $400 \mathrm{ml}$ \\
\hline
\end{tabular}

crease, encompassing a greater amount of tissue and allowing lower suturing in and direct view of the previously demarcated inframammary crease.

This study evidences that breast reconstruction with permanent tissue expanders is a suitable choice ${ }^{14}$, easy to learn, and simple to execute, with low morbidity and complication rates as well as good results, and prevents mutilation resulting from mastectomy. In our experience, the technique is adequate and the observed complications are inherent to any breast reconstruction after mastectomy.

Other studies should be conducted to improve the breast reconstruction techniques after mastectomy due to breast cancer.

\section{CONCLUSION}

The muscle flap based on the pectoralis major, pectoralis minor, serratus anterior, and rectus abdominis aponeurosis is a good choice for breast reconstruction with permanent tissue expanders. The technique provides adequate protection to the expander and the skin flap, enabling expansion without confinement of the device in the submuscular cavity. In this technique, the inframammary crease is repositioned by suturing the flap to the costal periosteum to ensure the natural shape of the reconstructed breast. In the expansion period, lateral or superior expander migration does not occur, which would harm the final outcome of the reconstruction. 

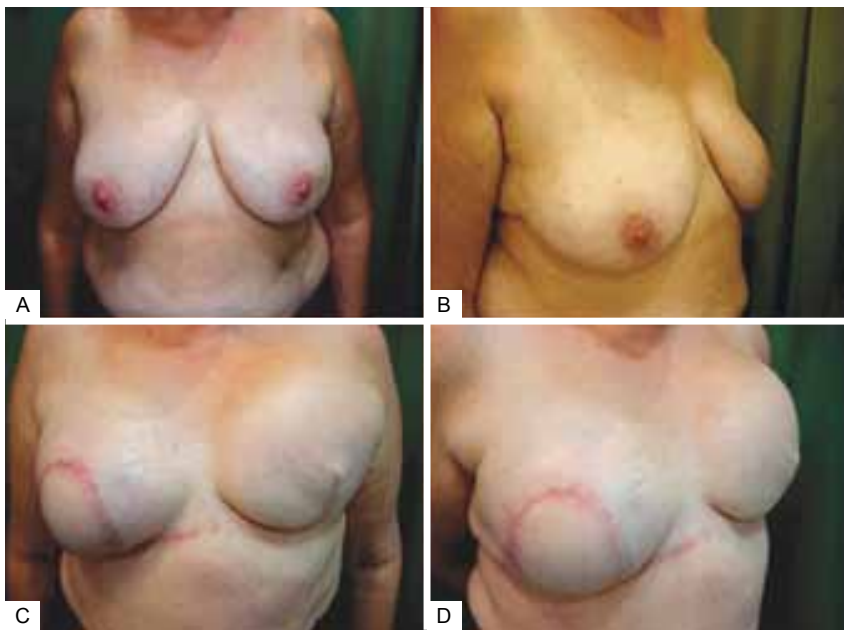

Figure 17 - Patient 14. Preoperative aspect. Rotated thoracic skin flap to cover the area of skin exposure.

This technique is easy to perform, requires no special or alloplastic materials, and allows direct visualization at the time of testing of the remote valve system, identifying any fluid leaks or obstructions in the valve-expander assembly.

\section{REFERENCES}

1. Instituto Nacional do Câncer. (National Cancer Institute) Controle do câncer de mama: documento de consenso. (Breast cancer control: consensus document) Rio de Janeiro: Instituto Nacional do Câncer; 2004. Available at: http://www.inca.gov.br/publicacoes/Consensointegra.pdf (Accessed on: 10/10/2006)

2. Sant'Ana DBA. Mulher e o câncer na história. (Women and cancer in history) In: Gimenes MGG, Fávero MH, eds. A mulher e o câncer. (Women and cancer) Campinas: Livro Pleno; 2000. p. 43-70.

3. Menke CH, Biazús JV, Xavier NL, Cavalheiro JA, Rabin EG, Bittelbrunn A, et al. Rotinas em mastologia. (Routines in mastology) $2^{\text {nd }}$ ed. Porto Alegre: Artmed; 2007.

4. Brasil. Ministério da Saúde. (Ministry of Health) Instituto Nacional do Câncer. (National Cancer Institute) Estimativa 2010: incidência de câncer no Brasil. (2010 estimation: Cancer incidence in Brazil) Rio de Janeiro: Instituto Nacional de Câncer; 2009.

5. Caponero R, Donato EMOD, Malzyner A. A metamorfose de uma angústia: o tratamento do câncer de mama de Halsted ao BRCA-1. (The metamorphosis of anguish: breast cancer treatment from Halsted to BRCA-1) In: Gimenes MGG, Fávero MH, eds. A mulher e o câncer. (Women and cancer) Campinas: Livro Pleno; 2000. p. 71-107.

6. Gabka CJ, Bohmert H. Cirurgia plástica e reconstrutiva da mama. (Plastic and reconstructive breast surgery) $2^{\text {nd }}$ ed. Porto Alegre: Artmed; 2010.

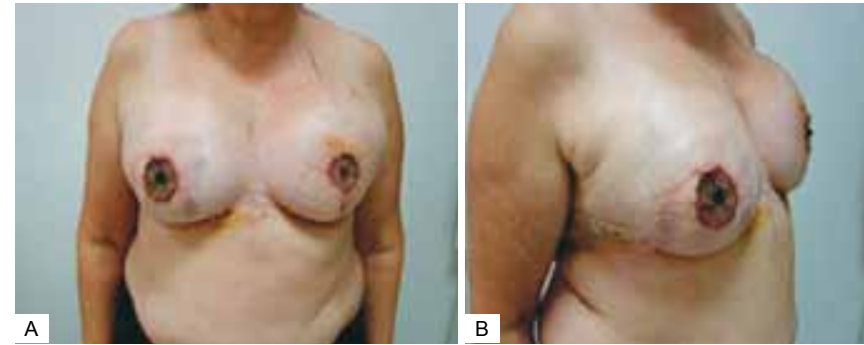

Figure 18 - Patient 14. Bilateral nipple-areolar complex reconstruction, breast size adequacy, and valve removal.
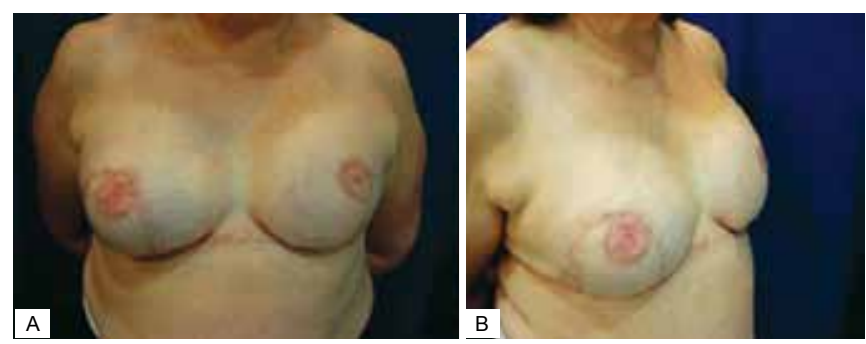

Figure 19-Patient 14. Final aspect of the reconstruction.

7. Pelay MJ, Oroz J, Colas C. Reconstrução da mama com expansor de próteses. (Breast reconstruction with prostheses expander) Anales Sis San Navarra. 2005;28 Suppl 2.

8. Spear SL, Mesbahi AN. Reconstrução com implantes. (Reconstruction with implants) In: Neligan PC, Lipa JE, eds. Reconstrução mamária pós-mastectomia: cirurgia plástica. (Breast reconstruction after mastectomy: plastic surgery) Rio de Janeiro: Dilivros; 2008. p. 81-96.

9. Guimarães GS, Daher JC, Cammarota MC. Reconstrução mamária com expansor permanente: uma outra alternativa. (Breast reconstruction with permanent expander: an alternative) Rev Bras Cir Plást. 2008;23(2):75-81.

10. Spear SL, Pelletiere CV, Lockwood M. Immediate breast reconstructions with tissue expanders and AlloDerm. In: Spear SL, ed. Surgery of the breast: principles and art. $2^{\text {nd }}$ ed. Philadelphia: Lippincott Williams \& Wilkins; 2006. p. 484-8.

11. Lifecell Corporation package insert. Branchburg: Lifecell Corp; 2004.

12. Becker H. One stage immediate breast reconstruction with adjustable implants. In: Spear SL, ed. Surgery of the breast: principles and art. $2^{\text {nd }}$ ed. Philadelphia: Lippincott Williams \& Wilkins; 2006. p. 438-50.

13. Becker H. The expandable mammary implant. Plast Reconstr Surg. 1987;79(4):631-7.

14. Avelar LET, Tostes ROG, Andrade Junior JCCG, Ribeiro GVC, Tavares MV. Reconstrução imediata do volume mamário com expansores permanentes. (Immediate reconstruction of breast volume with permanent expanders) Rev Soc Bras Cir Plást. 2007;22(3):162-9.

Correspondence to:

Rinede Luis Manfredini

Rua São Paulo, 466 - sala 1.206 - Centro - Erechim, RS, Brazil - CEP 99700-000

E-mail: cirurgiaplastica@awo.com.br 